\title{
INTRA-ORGANIZATIONAL ANTECEDENTS OF TALENT MANAGEMENT IN THE CONTEXT OF POSITIVE ORGANIZATIONAL SCHOLARSHIP: A STUDY OF COMPANIES OPERATING IN POLAND
}

Purpose: The aim of the study is to empirically validate the influence of talent management antecedents identified in the literature. The concept of talent management is discussed in the context of Positive Organizational Scholarship. This idea helped to prepare a more accurate enumeration of the antecedents of talent management presented in the literature. The analysis of the literature was the basis for developing a set of propositions which constitute the model to be tested empirically.

Methodology: The analyses presented in this paper were supported by the data collected in the questionnaire survey conducted among companies operating in Poland in 2012. The examined sample consisted of 73 organizations. Pearson correlation and partial least squares (PLS) path modelling were applied to analyze the causal relations between the variables.

Findings: The analysis positively validated the cause-effect relationships between talent management and the following antecedents: talent management infrastructure and organizational culture, organization strategy, and internal communication.

Research limitations: The study was limited to companies operating in Poland which established a specific cultural context. The relatively small research sample was another constraint. Therefore, the findings cannot be automatically extended to other organizations. Moreover, in order to reduce the observed ambiguity between causes and effects, quantitative studies should be supported by qualitative surveys based on the case study methodology.

Originality/value: The outcomes of the study contribute to the field through the empirical testing of the theoretical assumptions concerning the antecedents of talent management.

Keywords: talent management, Positive Organizational Scholarship, talent management antecedents

JEL Classifications: J24, M12, M14, M54

DOI: 10.15611 aoe.2020.2.10

\section{INTRODUCTION}

According to the assumptions of the resource-based view of strategic management only strategically valuable, rare, non-imitable and non-substitutable resources may become a foundation of a sustainable competitive advantage

\footnotetext{
* Institute of Management, WSB University in Torun.

** Faculty of Economic Sciences and Management, Nicolaus Copernicus University in Torun.
} 
(Barney, 1991). Due to the fact that talent seems to meet all the aforementioned requirements, talent management is considered to be a key process for organizational development and building competitive advantage (Heinen and O'Neill, 2004; Ashton and Morton, 2005; Lewis and Heckman, 2006). Talent management enables organizations to distinguish from their competitors which makes the role of talent management unquestionable. Talent and talent management have become the research topics of the studies conducted by the Gallup Institute. Moreover, positive psychology driven by Seligman's call to focus psychological studies on human strengths contributed to the rising interest in talent management (Seligman, 2004). The key assumption of this approach is the belief that focusing on human strengths and talents rather than on improving weaknesses provides much more efficiency and effectiveness (Clifton and Harter, 2003). Consequently, the concept of talent management and the idea of organizational development based on strengths have been included into Positive Organizational Scholarship (Cameron et al., 2003a). In order to achieve outstanding outcomes, in-born talent should be connected with knowledge and skills. The synthesis of talent, knowledge and skills is labelled as a strength (Buckingham and Clifton, 2003). Therefore contemporary organizations are recommended to make talents a foundation of their development and enable talents their development, and thus organizations need efficient and effective talent management programmes.

Talent management is a complex and challenging process which requires specific conditions to be implemented and provide positive outcomes. In Poland, talent management processes have not been fully developed yet. Generally, Polish managers are aware of the paramount importance of talent management. Nevertheless, numerous companies still admit that they lack formal talent management solutions or they are significantly weak in their talent management procedures. Therefore, the question arises about the antecedents of talent management. The models of talent management (Ashton and Morton, 2005; Tansley et al., 2007; Pocztowski, 2008; Collings and Mellahi, 2009) often theorize on talent management antecedents and determinants but they do not provide the empirical evidence to confirm these assumptions and identified relationships between variables. Having conducted literature studies of talent management antecedents, the authors have not come across any empirical papers confirming relations between talent management and the factors which determine it. Thus a gap in the knowledge base has been identified which stimulates research in the field.

The aim of the study is to empirically validate the influence of talent management antecedents identified in the literature. The paper consists of two parts: the literature survey and the empirical study. First of all, the idea of 
Positive Organizational Scholarship is discussed in order to establish the context for further studies. Secondly, the concept of talent management is explored. Thirdly, the antecedents of talent management enumerated in literature are presented. The analysis of the literature is the foundation to develop a set of propositions which constitute the model to be tested empirically. Fourthly, the method of study was described. Then, the analysis of correlations and regressions between the variables in the model was conducted. Finally, the findings from the empirical survey were discussed and the recommendations for further research formulated.

\section{LITERATURE REVIEW}

\subsection{Positive Organizational Scholarship as the context for research in talent management}

Positive Organizational Scholarship (POS) is one of the recently emerged concepts of management. In 2002, the Center for Positive Organizational Scholarship (nowadays known as the Center for Positive Organizations) was founded at the Ross School of Business, the University of Michigan. The publication entitled "Positive Organization Scholarship: Foundations of a New Discipline" edited by Cameron et al. (2003a) is considered to be the starting point of the positive approach in management studies. Certainly, Positive Organizational Scholarship refers to previous studies applying the humanistic perspective to management and it shares some similarities with other concepts and approaches in social sciences focusing on the positive aspects of management and human behaviour. The idea of Positive Organizational Scholarship is expressed in the name of the concept. 'Positive' refers to the orientation towards all the positive aspects, states, behaviours and attitudes. It assumes that the success of an organization should be developed on its strengths rather than on the improvement of weaknesses. 'Organizational' refers to the context of the study which is focused on organizational processes and states. 'Scholarship' means that the research methodology and scientific approach are applied to deal with the issues in the field (Cameron et al., 2003b; Pace, 2010). The attention of Positive Organizational Scholarship focuses on "the enablers (e.g. processes, capabilities, structures, methods), the motivations (unselfishness, altruism, contribution without regard to self), and the outcomes or effects (e.g. vitality, meaningfulness, exhilaration, high-quality relationship) associated with positive phenomena" (Cameron et al., 2003b).

Positive Organizational Scholarship represents the humanistic approach to management. Therefore, human resources management and talent management 
as its element are within the interest of POS studies. Human resources are enumerated among the intangible assets which constitute positive organizational potential (Glińska-Neweś, 2010; Chodorek, 2010). Positive organizational potential is defined as "the set consisting of resources related to strategy, structure, human resources management, power, control, innovations, company's integration and employees' identification, and leadership. Positive organizational potential refers to such characteristics and states of organizational resources that create positive organizational culture and positive organizational climate" (Peyrat-Guillard and Glińska-Neweś, 2010). The concept of positive organizational potential is particularly interesting as it helps explain the relationships between the positive bias of organizations and their development and performance (Haffer, 2010; Haffer, 2013). Hence it should be noted that talent management is identified among the key areas of positive organizational potential. There are also observed some efforts to identify and discuss the antecedents of talent management in the context of positive organizational potential studies (Chodorek, 2013; Karaszewski and Lis, 2014). Nevertheless these studies have a rather exploratory character and they lack the testing of cause-effect relationships between talent management and its antecedents proposed in the literature.

\subsection{Talent management}

Nowadays talent management is considered to be both one of the leading processes and challenges for managing human resources in business organizations (Heinan and O'Neill, 2004; Ashton and Morton, 2005; McCauley and Wakefield, 2006; Ingham, 2006). The talent management concept, which emerged in the U.S. in the 1990 s, seems to be a relatively well-grounded issue. However, one may assume that the area is affected by the same recurring problems which have not been solved and which are becoming more and more important. What is more, even the increasing number of studies resulting in business and scientific papers dealing with the issue has not changed the situation significantly.

As observed by Ashton and Morton (2005, p. 30), neither a common approach to nor a common definition of talent management had been yet developed. Although a decade passed since that observation, nothing has changed in this field (Vaiman and Collings, 2013). Talent management is defined at various levels (Lewis and Heckman, 2006) and from different perspectives. Blass et al., (2009) operationalize talent management from the perspectives of: a process, culture, competitiveness, development, human resources planning and change management shifting the centre of gravity in 
each perspective. Moreover, the issues of global talent management (Tarique and Schuler, 2010) and strategic talent management (Collings and Melahi, 2009) have been introduced to the literature. On the one hand, the focus of talent management is put on selecting the best employees, 'champions' (an elitist approach), but on the other, all employees may be perceived as talents and the role of talent management is to match properly their strengths with best suited positions in a company (an egalitarian approach) (Garrow and Hirsh, 2008; Reilly, 2008).

The most often cited definitions of talent management describe the construct as a set of activities and processes aimed at identifying, attracting, recruiting, selecting, developing, retaining and using high potential employees, who are extremely valuable for an organization (McCauley and Wakefield, 2006; Tansley et al., 2007). Recognizing the abundance and variety of approaches in the literature, the following definition describing the ideal state of talent management is accepted for further analyses and discussions: "The model talent management encompasses the processes of searching, identifying, attracting and recruiting people of above-average intellectual potential and skills as well as developing and applying their capabilities in order to contribute to the company's aspirations and needs" (Chodorek, 2013). Recognizing and selecting the most talented employees is an investment in the company's human capital. As charisma, skills and energy of employees are the key antecedents of company performance, contemporary companies fight the "wars for talents" (Beechler and Woodward, 2009).

In order to result in effective outcomes, talent management must be perceived and implemented in the long-term perspective. One-time programs are ineffective. Such activities are usually expensive and temporary. Their aims are not clearly defined. In effect, employees who acquire new skills and capabilities are not able to make use of them in their workplaces which results in employee frustration. Thus applying the strategic approach to talent management seems to be the prerequisite while identifying the positions of the key impact on an organization is a fundamental activity in the strategy development process (Collings and Melahi, 2009). Strategic talent management enables an organization to build up a relevant architecture of human resources necessary to change the behaviour of employees in order to improve their effectiveness. The strategic approach to managing talent facilitates identifying the key activities of a company and to define specific requirements for employees to achieve strategic objectives at the highest possible level (Minbaeva and Collings, 2013; Guthridge, et al., 2008).

The strategic approach to talent management enables a company to plan the requirements for specific talents. Due to a long-term planning perspective, 
an organization is able to define who (a person characterized by a set of given capabilities) is necessary for its development and verify whether it has such an employee (Asthon and Morton, 2005). As a consequence, an organization knows what kind of talent is needed, which enables managers to plan for talents. Detailed job descriptions support such a planning process. Defining competencies is the foundation for searching talents both within an organization and outside it (Pilbeam and Corbridge, 2010).

The relevant methods and tools of talent identification, recruitment and selection are necessary for managing talents in an efficient and effective way. The analysis of recruitment forms, psychological tests, assessment centres and interviews have become the prerequisites for identifying, recruiting and selecting high potential employees (Elegbe, 2010).

Another important aspect of talent management is building such a position of a company on the market to attract the best employees. The activities aimed at creating the company image as an optimum choice for a working place are defined as employer branding (Surmacz and Bociaga, 2011). The scope of such activities is wide and their aim is to highlight the distinctive features of an organization (of economic, psychological, cultural, functional character) which may be attractive for a potential, talented employee (Yaqub and Khan, 2011).

Retaining talented employees and maintaining the high level of their commitment is a challenge for a company. Therefore, companies continuously make efforts to seek an answer to the question of how to retain talented personnel (Kaye and Jordan-Evans, 2012). This is a complex issue determined by the variety of factors related to personality, values, a specific situation of an organization and what it offers to employees. Talented employees should be treated individually, therefore companies establish for them individual development paths and enable them to grow in a continuous way (Ahmadi, et al., 2012). The most popular methods of developing talent include: participation in company projects, training, mentoring, coaching, job rotation, participation in international projects and internships abroad (Jarosławska, 2011).

Team work establishes the conditions for the most efficient and effective use of the potential of talented employees. Besides applying their skills and competencies, high potential employees share knowledge as well as teach their colleagues and learn from them (Calo, 2008). The process of knowledge exchange may be more efficient when employees have possibilities to inspire the development of teams. The awareness of being the font of knowledge for others, and having the opportunity to benefit from the knowledge of workmates increases employee satisfaction. In order to achieve such a situation, cooperation and the mutual enhancing of motivation are embedded as ground rules into the culture of an organization (Reed, 2001). 
Nowadays the importance of talent management processes is commonly accepted and managers are aware of their roles and outcomes. Moreover, research shows that talent management has become one of the priorities for HR managers who consider attracting talented employees among their most crucial tasks (Trendy HR, 2013). If talent management is a priority for Polish companies then why so many managers declare problems and challenges in managing talent and implementing talent management processes in their companies? The study conducted by Deloitte reveals that half of Polish managers participating in the survey claim that talent management programs in their companies require substantial or radical changes (Deloitte, 2013). Hence, a question arises: what are the antecedents of talent management which determine the success of TM programs?

\subsection{Intra-organizational antecedents of talent management}

There is a variety of publications which mention and study some selected factors influencing talent management. Nevertheless, a comprehensive analysis of talent management antecedents has not been completed as yet.

It may be assumed that a clear company strategy oriented to talent management is the basis for planning and implementing a talent management program. Such a strategy enables a company to identify core competencies and plan succession (Tansley et al., 2007; McDaniel and D'Egidion, 2010). It is obvious that a company cannot manage talents in an efficient and effective way without being aware of its aims and objectives. A company aims to determine the level of employee skills and competencies which are required at present and may be needed in the future. Consequently, they enable companies to plan which talents are/will be necessary and how to develop the talents at the company's disposal (Sloan et al., 2003). Moreover, clearly defined aims are important from the point of view of talented employees. They help them to identify their roles in achieving company aims and their individual impacts on these aims (Turning talent into strategic assets, 2010).

Proposition 1: The company strategy determines talent management both directly and indirectly.

The architecture of the human resources management system is another important aspect determining talent management. Such an HR system should support the value and uniqueness of employee skills and competencies (Collings and Melahi, 2009). Williamson (2011) claims that the transparency of the talent management system is a key to its success and it enhances the credibility of this system. Talent management must be transparent to all 
employees, and the principles governing the selection of high potential employees and their privileged treatment must be understandable and clear for every organization member. Such transparency goes beyond selecting talented employees and it applies, among others, to remuneration policies, measuring work effectiveness and appointing to all positions (Garrow and Hirsh, 2008; Bryan and Joyce, 2007). A transparent and clear talent management system prevents any disputes, frustrations and subjectivity of personnel assessment. It gives employees the feeling of psychological comfort and enables them to identify their achievements (Koziński and Witkowska, 2009; Blass, 2009; Merlino, 2011). Moreover, an organization needs formal preparation to implement a talent management program to effectively manage high potential employees. The ability to develop and apply tools and techniques for identifying strategic capabilities of talented employees is another prerequisite for a talent management program. Knowing what company employees know and what skills and competencies are still needed is valuable knowledge (Mayo, 2009). Such tools and techniques facilitate the identification, recruitment and selection of talented employees. A motivation system responsive to talented employees' aspirations and their attitudes to work is another important formal aspect of a talent management infrastructure (Mayo, 2009; Ahmadi et al., 2012). Summing up, a talent management infrastructure encompasses formal solutions (processes, techniques, tools) applied by organizations within the field of talent management.

Proposition 2: A talent management infrastructure determines the talent management process.

Organizational culture belongs to those talent management antecedents which are most often mentioned in the literature (Bryan and Joyce, 2007; Ashton and Morton, 2005; Ahmadi et al., 2012; Kopeć, 2012; Tabor, 2013). Organizational culture favourable for talent management is described as a 'talent-nurturing culture'. Organizational culture should support talented employees, promote their 'difference' from others and creativity as well as reward and recognize employees of distinctive achievements. In contrast, organizational culture persecuting employees for their willingness to go beyond standard procedures and hierarchy prevents talents from emerging and blooming (Tabor, 2013). It is of paramount importance to have top executives showing the value of talent management for an organization. Without support from top management, any talent management initiatives are doomed to fail. If leaders do not believe in talent management, neither will their followers. This means that the belief in talent management and effective leadership are 
important prerequisites of talent management (Ellehuus, 2012; Ahmadi et al., 2012; Ashton and Morton, 2005).

Within an organizational culture supporting talent management, two aspects of company social capital are highlighted: trust and high quality relationships (Vaiman et al., 2012). Trust is perceived as a trigger and a motivation factor fostering talent management (Tansley et al., 2007). The relevant level of trust in an organization fosters achieving its aims, facilitates knowledge sharing and stimulates the employee identification with an organization and their corporate patriotism. As a consequence, the principles of a talent management program are commonly accepted, employees are eager to express their opinions, they behave frankly and team work is appreciated and developed (Sosińska, 2007).

Positive relationships establish the foundation for a talent management system. Hard working and effective employees show more willingness to engage in behaviour-building and strengthening high quality relationships which gives them an opportunity to benefit from such relationships e.g. receive the assistance of their co-workers when needed. Good relationships trigger a spiral of positive emotions and make people enjoy their work (Sekerka et al., 2012). As a consequence, employees are loyal to such organizations and show the maximum level of engagement which significantly contributes to the development of talented employees and their potential (Kaye and JordanEvans, 2012). Relationships are an important factor impacting on talented employees' work quality and willingness to work. Due to the fact that relationships go across the boundaries between departments, locations, fields of expertise and hierarchy, talented employees are able to find the niches and areas in an organization which are not fully exploited.

Proposition 3: Organizational culture determines talent management.

Corporate social responsibility (CSR) is a construct and an area of company activity directly related to organizational culture, trust and positive relationships. More and more often, companies implement the concept of corporate social responsibility in order to be distinguished from competitors and develop their positive image. Corporate social responsibility is a useful tool applied to attract and retain talented employees. Therefore numerous companies perceive corporate social responsibility as an important element of their HR strategies (Vaiman et al., 2012; Kim and Scullion, 2011). In the contemporary labour market, high salaries are not sufficient to attract talented employees seeking some other values highlighted by the CSR concept. Organizations taking into account the interests of society, environmental aspects and their relationships with stakeholders (employees in particular) assume a higher level of 
investments in human resources. Such organizations are supposed to create good working conditions, support employee development and take care of employees in need (e.g. those suffering from illness). All these interventions motivate employees and increase engagement in performing their duties (Kim and Scullion, 2013).

Proposition 4: Corporate social responsibility determines talent management.

Communication and communication skills are talent management antecedents often cited in the literature (Ulrich et al., 2012; Garrow and Hirsh, 2008). Transparent and open communication is postulated in order to foster talent management programs. The research shows that supportive communication providing employees with information about their higher status leads to better work performance and an increase in employee loyalty to their company (Fernandez-Araoz et al., 2012). Companies should also pay attention to the way they are communicating with talented employees (transparency of messages, programs and objectives) (Koziński and Wiskowska, 2009; Ahmadi et al., 2012). Employers and managers should focus their attention on building effective communication systems both within an organization and outside it due to the fact that it enhances the speed of information exchange between employees as well as between employees and managers. Moreover, effective communication systems are required for team work, in particular when team members cooperate from distant locations. Last but not least, effective communication fosters organizational culture which values knowledge as a common valuable asset (Zydel, 2010; Piskorski et al., 2010).

Proposition 5: An effective communication system determines talent management.

Creating development opportunities for talented employees is another antecedent worth mentioning and analyzing. Talented employees need stimulants, new challenges and ambitious aims to be achieved (Pilbeam and Corbridge, 2010; Kaye and Jordan-Evans, 2012). From the point of view of high potential employees, the prospects for professional development are important motivations for joining an organization and being loyal to it. Talented employees need challenges, possibilities to participate in projects, decision-making processes and connecting their tasks with a business strategy (Talent management is Bupharm's prescription for success, 2011; Cunningham, 2007; Ulrich et al., 2012; Garrow and Hirsh, 2008). Due to such elements, talented employees feel the importance of their roles in an organization and 
their possibilities to have an influence on the company's future through their engagement, knowledge and skills. A strategic approach to the development of employees is manifested, among others, through career paths which establish plans for talents climbing the ladder of the organizational hierarchy. Career paths are considered to be both a manifestation and an antecedent of talent management.

Proposition 6: Creating development opportunities for talented employees determines talent management.

Organizational structure is another talent management antecedent enumerated in the literature (Ashton and Morton, 2005; Tansley et al., 2007). The aspects of organizational structure which are important for managing talents include: the level of centralization (the lower centralization the better) and a hierarchy (balance between flattening an organizational structure and establishing conditions for career paths and promotions) (Garrow and Hirsh, 2008; Blass, 2009). Bryan, et al. (2006) argue that tall organizational structures impede identifying talents, searching the opportunities for their development and creating organizational knowledge. An organizational structure should facilitate team work and create favourable conditions for establishing flexible project teams. This is of paramount importance for acquiring and sharing knowledge which leads to improvements and innovations. Talented employees free from the pressure of bureaucratic procedures are more eager to show creativity in their workplaces and improve the work of themselves and other personnel.

Proposition 7: Organizational structure determines talent management.

Middle-level managers, their knowledge and competencies seem to play a significant role in talent management programs. They contribute to talent management processes through identifying high potential employees, supporting their development and creating career paths (Tansley et al., 2007). Middle-level managers motivate talented subordinates to seek the possibilities for professional development and make above-the-standard efforts (Bryan and Joyce, 2007). On the other hand, a toxic middle-manager may be the first-line 'killer' of talented employees.

Proposition 8: The quality of middle-level management determines talent management.

Summing up, the authors propose a comprehensive model of the talent management antecedents presented in Figure 1. The numbers in Figure 1 refer to the aforementioned propositions. 


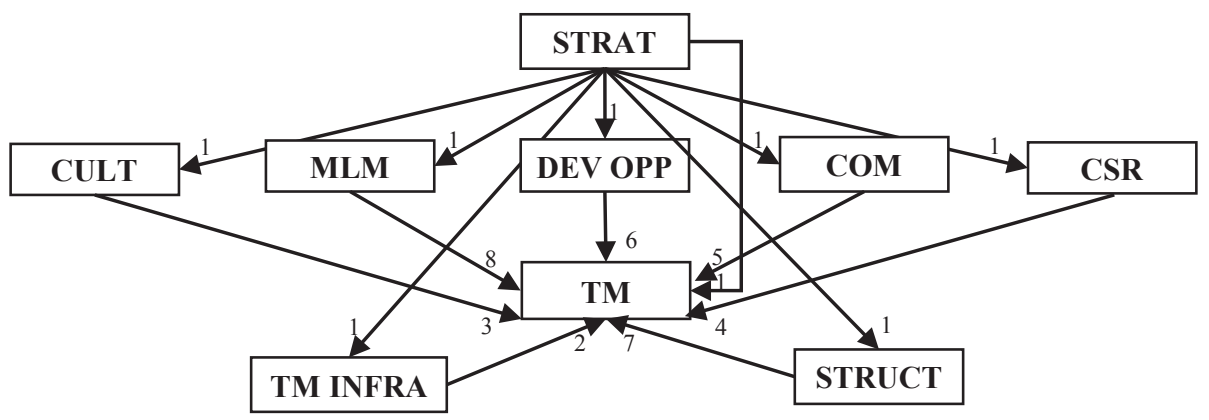

Notes: Variables: TM - talent management; STRAT - strategy; CULT - organizational culture; MLM - middle level management; DEV OPP - development opportunities for talented employees; COM - organizational communication; CSR - corporate social responsibility; TM INFRA - talent management infrastructure; STRUCT - organizational structure.

Fig. 1. The antecedents of talent management

Source: own elaboration.

\section{EMPIRICAL STUDY}

\subsection{Method of research}

The data presented in this paper come from the research project entitled "Strategic management of the key areas of Positive Organizational Potential (POP) - conditions, approaches and models recommended for companies operating in Poland". The project was funded by the National Science Centre grant no. DEC-2011/01/B/HS4/00835. The project was based on four complementary data and information elicitation methods, namely a questionnaire survey, interviews, a Delphi session and a classic Delphi (by correspondence). This paper concentrates on the results of the questionnaire survey. The data were completed in 2012. The sample comprising 73 companies was selected from organizations operating in Poland recognized as the leaders in their industries (or at least as top ranking companies).

The respondents were asked to assess the accomplishments of the companies they managed in nine areas, based on the eleven grade scale $<0 \%$, $10 \%, 20 \%, \ldots, 100 \%>$ where $0 \%$ refers to the situation when the ideal feature definitely does not characterize an assessed area, $100 \%$ refers to the situation when the ideal feature definitely characterizes an assessed area. These areas are as follows: talent management (TM), strategy (STRAT), organizational culture (CULT), middle level management (MLM), development opportunities 
for talented employees (DEV OPP), intra-organizational communication (COM), corporate social responsibility (CSR), talent management infrastructure (TM INFRA), organizational structure (STRUCT). The manifest variables describing the aforementioned latent variables are available in the appendix. In order to test the reliability of the questionnaire, Cronbach's alpha coefficients were calculated for nine variables corresponding with the above-mentioned areas included in the questionnaire. Cronbach's alpha coefficients ranged from .82 to .97 which confirms the high level of the questionnaire reliability.

As the dominant scale used in the questionnaire was a percentage scale which is a ratio scale, the Pearson correlation and PLS path modelling together with appropriate statistical tests were applied to analyse the causal relations between variables. IBM SPSS Statistics and SmartPLS (Ringle, Wende, and Will, 2005) software were used for statistical analyses. The majority of the estimates were made on the basis of the generalization of the subjective assessment of the managers. In this way it was possible to identify the determinants of talent management in companies operating in Poland. The enumerated variables constitute the foundation for the comprehensive model of talent management antecedents presented in Figure 1.

\subsection{Research analysis}

The analysis of correlations and regressions was applied to validate the propositions included into the model. First of all, in order to confirm the relationships among the variables, the analysis of correlations was conducted (Table 1).

Table 1

Correlation analysis of the model of talent management antecedents,

Pearson correlation coefficients, $\mathrm{p}<0.01$

\begin{tabular}{l|l|c|c|c|c|c|c|c|c}
\hline \multicolumn{2}{l|}{ Variables } & 1 & 2 & 3 & 4 & 5 & 6 & 7 & 8 \\
\hline 1 & TM INFRA & 1.000 & & & & & & & \\
\hline 2 & CULT & .784 & 1.000 & & & & & & \\
\hline 3 & DEV OPP & .848 & .858 & 1.000 & & & & & \\
\hline 4 & MLM & .832 & .850 & .795 & 1.000 & & & & \\
\hline 5 & COM & .798 & .862 & .814 & .790 & 1.000 & & & \\
\hline 6 & CSR & .824 & .722 & .719 & .754 & .777 & 1.000 & & \\
\hline 7 & STRAT & .664 & .660 & .700 & .717 & .676 & .700 & 1.000 & \\
\hline 8 & STRUCT & .715 & .772 & .831 & .702 & .824 & .672 & .650 & 1.000 \\
\hline 9 & TM & .781 & .760 & .681 & .725 & .756 & .714 & .627 & .626 \\
\hline
\end{tabular}

Source: own elaboration. 
The analysis shows that all the identified antecedents strongly correlate with talent management, which confirms the important relationships between the variables. The top correlates are: talent management infrastructure $(\mathrm{r}=.781)$, organizational culture $(\mathrm{r}=.760)$ and internal communication $(\mathrm{r}=.756)$. Simultaneously, it should be highlighted that strong correlations are observed between all the variables included in the model.

In the case of the correlation coefficients referring to the pair of variables, it cannot be stated which of the two is the cause or the effect. One can only refer to the existence of correlation between them. That is why the PLS path modelling was carried out to test the proposed model of talent management antecedents and show the cause-effect relations between the variables. The main idea of the PLS regression analysis is data prediction, forecasting for a given variable on the basis of other variables.

Figure 2 shows the model estimation results. The path coefficients allow the assessment of the impact of predictor (independent) constructs on endogenous (dependent) constructs, represented by rectangles with arrow heads. The higher their value, the stronger their impact, as the path coefficients represent the estimated change in the endogenous variable for a unit change in a predictor variable.

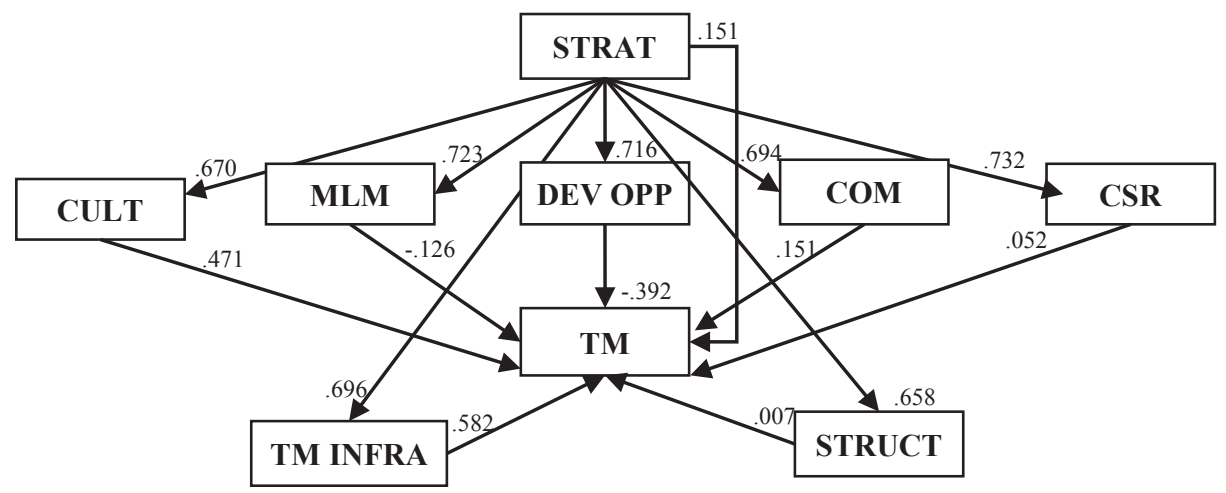

Notes. Variables: TM - talent management; STRAT - strategy; CULT - organizational culture; MLM - middle level management; DEV OPP - development opportunities for talented employees; COM - organizational communication; CSR - corporate social responsibility; TM INFRA - talent management infrastructure; STRUCT - organizational structure.

Fig. 2. The PLS regression analysis of talent management antecedents

Source: own elaboration. 
According to the data, the increase in the STRAT construct will have a strong positive impact on all dependent constructs excluding TM, in which case the direct impact will be positive but rather weak. However the total (direct and indirect - through the other variables) effect of the increase in STRAT on TM will be positive and strong as in this case $\beta=.647$. This means that the improvement in the quality of strategy in companies as regards taking employees' opinions into consideration when creating it as well as genuine communicating of goals and a range of their achievement to employees will result in the improvement of the talent management quality. This can result in the inclusion of talent management in the strategy as well as in more advanced talent management practices, e.g. individual career paths applied for talented employees or advanced methods of attracting the best employees available in the labour market. Furthermore, the high total effect of STRAT on TM is caused in particular by the high value of path coefficients between the STRAT and two other variables CULT $(\beta=.670)$ and TM INFRA $(\beta=.696)$ which in turn have a big impact on TM. This means that effective talent management is determined by cultural issues like a high level of trust and positive interpersonal relationships present in a company and a highly developed talent management infrastructure including high quality HR policies and procedures respecting employee interests. Both factors influencing effective talent management strongly depend on the strategy quality.

The relationships between the STRAT and the other variables observed on the basis of path coefficients are not surprising, since the strategy and individual policies included in it determine all the areas of a company's functioning. However, the results regarding the relationships between TM and its determinants are more surprising.

As was mentioned above, the path coefficients shown in Figure 2 indicate that the strongest positive impact on the TM variable will be caused by the increase in the TM INFRA and CULT variables (strong direct impact), next in the STRAT variable (strong total effect), and then in the COM variable (weak direct impact, $\beta=.151$ ). The latter variable concerns organizational communication. It appears that the improvement in organizational communication as regards comprehensiveness and clarity of information and values communicated in a company will result in the improvement of the talent management quality, however this impact will be weak. In the case of the STRUCT and CSR variables reflecting transparent and teamwork-oriented organizational structure and corporate social responsibility initiatives maximizing the value of strategic stakeholders of a company, no impact on the TM variable was confirmed $(\beta=.007$ and $\beta=.052$ respectively). 
Finally, it can be seen in Figure 2 that two path regression coefficients from the MLM construct to the TM construct and from the DEV OPP construct to the TM construct take negative values ( $\beta=-.126$ and $\beta=-.392$ respectively), which means that the improvement in the quality of middle-level management as well as in the development opportunities created for talented employees will result in the decrease in talent management sophistication. These are the most surprising results, however they may suggest that the direction of the considered relationships should be reversed, especially when it comes to the latter one, namely DEV OPP-TM.

\subsection{Discussion}

The data presented and analysed above enable the authors to test the propositions formulated as a result of literature studies. As a result of the research, the propositions may be divided in three categories. In case of the first category including organizational strategy, talent management infrastructure, organizational culture and internal communication, the research confirms their influence on talent management. The second category of variables (corporate social responsibility and organizational structure) shows minimal (almost unnoticeable) cause-effect relationship with talent manage-ment. The most surprising results are achieved in regard to development opportunities for talented employees and middle-level management which represent negative values of the regressions coefficients.

Proposition 1 was validated. Clear strategy determines talent management and directly influences other talent management antecedents identified in the model. Similarly, Proposition 2 was confirmed by the empirical research. In order to manage talents in an efficient and effective way, organizations need tools, methods and clear procedures. Without an appropriate infrastructure, hardly any stage in the talent management process can be effectively completed. Undisputedly, talent management is determined by the organizational culture which confirms Proposition 3. Talents should be considered as something valuable by all the members of an organization. This finding was confirmed in interviews conducted in Polish companies. As noted by one of the HR managers: "an organization must be ready for talent management programmes with its values, attitudes, behaviour, but first and foremost with a high level of trust and intra-organizational relationships". The findings $(\beta=.151)$ prove that intra-organizational communication has some moderate influence on talent management which enables us to validate Proposition 5. Without unambiguous communication and feedback to high potential 
employees, it may be impossible to effectively implement talent management policies.

As regards corporate social responsibility, there are no findings to confirm its impact on talent management. A low value of the regression coefficient $(\beta=.052)$ demonstrates that its influence is very weak (almost unnoticeable). While observing business reality, this finding seems to be logical. Corporate social responsibility may be supportive for talent management but it does not determine talent management processes. Corporate social responsibility contributes to building a positive image of an organization which may attract new talents and establish a better working environment for employees. This means that Proposition 4 was disproved. Similarly to corporate social responsibility, organizational structures may support talent management programs. However, it is not possible to point out what type of organizational structure is optimal from the perspective of talent management, as it depends on the size of the company and its characteristics. Therefore, Proposition 7 could not be validated as the data of the survey do not confirm the impact of the organizational structure on talent management.

Proposition 6 was disproved, which is surprising. Almost every publication related to talent management highlights the role of creating development opportunities for talented employees as the basis for attracting and maintaining high potential employees. However, the development opportunities for talented employees (such as rewarding innovative employee behaviour, sophisticated training system, entitlements delegation in order to empower lower level employees etc.) can be created before a formalized, systemic approach to talent management is established in a company and inversely they can be a result of effective talent management. Similarly, Proposition 8 was refuted. In the opinion of the respondents, middle-level managers are not perceived as a force significantly influencing talent management. The authors admit that this was surprising for them while comparing the empirical findings with the outcomes of literature studies and even common sense. Middle- and first-line managers seem to be the first ones who can identify talented employees, shape their career paths and assign them to the tasks where their talents can flourish. In the opinion of the authors, two explanations for these findings are possible. The first interpretation could be that the more competent and inspiring for their people the middle managers, the smaller the need to develop in a company a talent management system as the middle managers play their coaching role for talents very well. The second explanation for the observed lack of the cause-effect relationship between middle managers and talent management programs relates to the influence of Polish culture on the organizational cultures of the companies under study. In Polish culture, 
standing out from the crowd and being a "star" is not commonly accepted (cf. Skuza et al., 2013, p. 461). Therefore, if middle managers represent such values and they are afraid that high potential employees can outperform them, any talent management initiatives will be hampered. Moreover, such managers do not contribute to talent management processes, which was observed by the respondents in the studied companies. It should be highlighted that such attitudes of managers ought to be altered.

The regression coefficients in this study indicate the reverse direction of the relationship between the development opportunities and talent management $(\beta=-.392)$, as well as middle level management and talent management $(\beta=-.126)$, which may suggest that in the aforementioned pairs of variables talent management is an antecedent, while the variables representing development opportunities and middle management should be considered as the outcomes of effective talent management programs. Thus in order to test such an assumption the model was changed and recalculated (Figure 3).

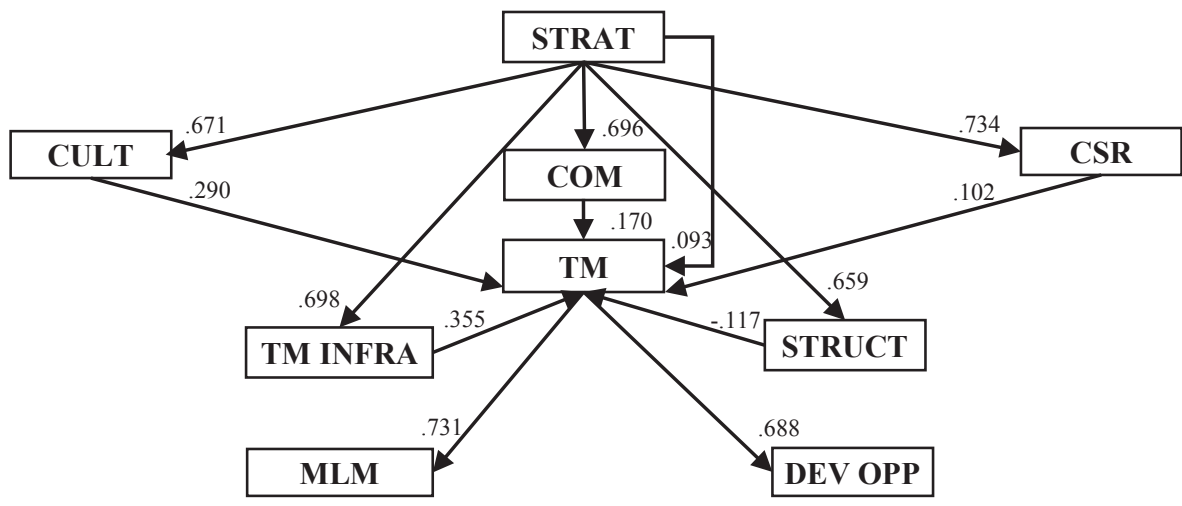

Notes. Variables: TM - talent management; STRAT - strategy; CULT - organizational culture; MLM - middle level management; DEV OPP - development opportunities for talented employees; COM - organizational communication; CSR - corporate social responsibility; TM INFRA - talent management infrastructure; STRUCT - organizational structure.

Fig. 3. The PLS regression analysis of talent management antecedents and consequents

Source: own elaboration.

This time the relationship between the talent management variable and the development opportunities variable, presented in Figure 3, is opposite and can be described as follows: the increase in the talent management construct will have a strong positive impact on the development opportunities construct. In such a case it is possible to indicate effective talent management consequences 
which can occur in the examined companies. These are the above-mentioned rewards for innovative employee behaviour, sophisticated training system and entitlements delegation in order to empower lower level employees, but also ambitious goals set for employees, high level of employee autonomy and responsibility and a result-dependent salary system.

The interpretation of a path regression coefficient in the case of a reverse talent management - middle-level management relationship is as follows: the increase in the talent management construct will have a strong positive impact on the middle-level management construct, which means that the improvement in the talent management system effectiveness will result in the improvement of the efficiency of middle level management. In this case, taking into account the whole model indicated in Figure 3, the quality of middle-level management is determined by well-thought-out and well communicated strategy and effective talent management system, which for its effectiveness needs to be created and managed from the strategic, rather than the middle-level perspective.

As a consequence of the changes in the model, high values of path coefficients were observed (TM-DEV OPP $\beta=.688$; TM-MLM $\beta=.731$ ) which confirms the assumption. There is some logic in the observed relationship between managing talents and creating for them development opportunities and middle level management. In order to enable employees their professional development adjusted to their strengths and talents, organizations should to be able to identify and select such high potential employees as well as create individual career paths which require effective talent management solutions.

The aforementioned findings seem to be interesting but they need further exploration. At the same time it should be mentioned that, as a side effect of the changes introduced in the model, the impact factor of such antecedents as organizational culture, talent management infrastructure and organizational strategy decreased.

\section{CONCLUSION}

The study has empirically tested the influence of talent management antecedents identified through literature surveys. The analysis encompassed eight categories of factors enumerated among the determinants of talent management programs: organizational strategy, organizational culture, middle-level management, development opportunities for talented employees, internal communication, corporate social responsibility, talent management infrastructure and organizational structure. 
The analysis based on the data of the questionnaire survey conducted in companies operating in Poland positively validated the cause-effect relationships between talent management and the following antecedents: talent management infrastructure and organizational culture (strong direct impact), organization strategy (strong total effect, mainly triggered by the indirect impact), and internal communication (weak direct impact). The study refuted the propositions on the role of organizational structure and corporate social responsibility in fostering talent management programs. As regards creating development opportunities for talented employees and middle-level management influence on talent management, ambiguous results were achieved. In both cases, the regression analysis showed a negative causeeffect between these factors claimed to be antecedents and talent management. In order to investigate these ambiguities thoroughly, the direction of the causeeffect relationships between the variables in the model was changed. As a result, the analysis confirmed that the increase in the talent management construct will have a strong positive impact on the development opportunities and middle-level management constructs.

The outcomes of the study contribute to the field through the empirical testing of theoretical assumptions concerning the antecedents of talent management. Nevertheless, it should be stressed that the study was limited to companies operating in Poland which established a specific cultural context. A relatively small research sample was another constraint. Therefore, the findings cannot be automatically extended to other organizations. The complexity of organizations results in difficulties to unambiguously distinguish between causes and effects. Therefore, this study should be considered as the first attempt to empirically validate the antecedents of talent management and should be followed by further quantitative research conducted in the international context and based on larger samples. Moreover, in order to reduce the observed ambiguity between causes and effects, quantitative studies should be supported by qualitative surveys based on the case study methodology.

\section{REFERENCES}

Ahmadi, A. A., Ahmadi, F., Abbaspalangi, J., Talent management and succession planning, "Interdisciplinary Journal of Contemporary Research in Business", 4(1), pp. 213-224, 2012.

Aston, C., Morton, L., Managing talent for competitive advantage, "Strategic HR Review", 4(5), pp. 28-31, 2005. 
Barney, J., Firm resources and sustained competitive advantage, "Journal of Management", 17(1), pp. 99-120, 1991.

Beechler, S., Woodward, I. C., The global "war for talent", "Journal of International Management", 15(3), pp. 273-285, 2009.

Blass, E., Systems and structures to support talent management [in:] Blass, E. (ed.), Talent Management: Cases and Commentary. Palgrave Macmillan, New York 2009.

Blass, E., Brockhoff, S. N., Oliveira, F. G., A map of the territory between HRM and talent management [in:] Blass, E. (ed.), Talent Management: Cases and Commentary. Palgrave Macmillan, New York 2009.

Bryan, L. L., Joyce C. I., Mobilizing Minds: Creating Wealth from Talent in the 21st-century Organization. McGraw-Hill, New York 2007.

Bryan, L. L., Joyce, C. I., Weiss, L. M., Making a market in talent: A 21st-century company should put as much effort into developing its talented employees as it puts into recruiting them, "McKinsey Quarterly", 2, pp. 98-109, 2006.

Buckingham, M., Clifton, D. O., Teraz odkryj swoje silne strony [Now, discover your strengths]. MT Biznes, Warsaw 2003.

Calo, T. J., Talent management in the era of the aging workforce: The critical role of knowledge transfer, "Public Personnel Management", 37(4), pp. 403-416, 2008.

Cameron, K. S., Dutton, J. E., Quinn, R. E. (eds.), Positive Organizational Scholarship: Foundations of a New Discipline. Berrett-Koehler Publishers, San Francisco 2003a.

Cameron, K. S., Dutton, J. E., Quinn, R. E., Foundations of Positive Organizational Scholarship [in:] Cameron, K. S., Dutton, J. E., Quinn, R. E. (eds.), Positive Organizational Scholarship: Foundations of a New Discipline. Berrett-Koehler Publishers, San Francisco 2003b.

Clifton, D. O., Harter, J. K., Investing in strengths [in:] Cameron, K. S., Dutton, J. E., Quinn, R. E. (eds.), Positive Organizational Scholarship: Foundations of a New Discipline. BerrettKoehler Publishers, San Francisco 2003.

Chodorek, M., Stan pozytywnego potencjalu w polskich przedsiębiorstwach - wyniki badań [The status of positive potential in Polish entreprises - research findings] [in:] Stankiewicz, M. J. (ed.), Pozytywny Potencjat Organizacji: Wstęp do użtecznej teorii zarzqdzania [Positive Organizational Potential: The introduction to the positive theory of management]. TNOiK Dom Organizatora, Toruń 2010.

Chodorek, M., The role of talent management in creating pro-developmental outcomes of positive organizational potential [in:] Stankiewicz, M.J. (ed.), Positive Management: Managing the Key Areas of Positive Organizational Potential for Company Success. TNOiK Dom Organizatora, Torun 2013.

Collings, D. G., Mellahi, K., Strategic talent management: A review and research agenda, "Human Resource Management Review", 19( 4), pp. 304-313, 2009.

Cunningham, I., Talent management: Making it real, "Development and Learning in Organizations: An International Journal”, 21( 2), pp. 4-6, 2007.

Dalziel, M. M., Formulating competencies [in:] Berger, L. A., Berger, D. R. (eds.), Talent Management Handbook: Creating a Sustainable Competitive Advantage by Selecting, Developing and Promoting the Best People. McGraw-Hill, New York 2011. 
Deloitte, Elastyczność i zmiana horyzontów: Trendy HR [Flexibility and change of horizons: HR Trends. Deloitte, 2013. http://www2.deloitte.com/content/dam/Deloitte/pl/Documents/ Reports/pl_Raport_trendyHR\%202013_PL_1.pdf (accessed: 25.10.2015).

Elegbe, J. A., Talent Management in the Developing World: Adopting a Global Perspective. Ashgate Publishing, Burlington 2010.

Ellehuus, Ch., Transforming business leaders into talent champions, "Strategic HR Review", 11, pp. 84-89, 2012.

Fernandez-Araoz, C., Groysberg, B., Nohria, N., Jak dbać o pracowników o wysokim potencjale" [How to hang on to your high potentials], "Harvard Business Review Polska", pp. 60-69, 2012.

Garonzik, R., Larrere, J. B., Creating the workforce of the future: Projecting and utilizing new competencies [in:] Berger, L. A., Berger, D. R. (eds.) Talent Management Handbook: Creating a Sustainable Competitive Advantage by Selecting, Developing and Promoting the Best People. McGraw-Hill, New York 2011.

Garrow, V., Hirsh, W., Talent management: Issues of focus and fit, "Public Personnel Management”, 37(4), pp. 389-402, 2008.

Glińska-Neweś, A., Pozytywny Potencjat Organizacji jako prorozwojowa architektura zasobów przedsiębiorstwa [Positive Organizational Potential as a pro-developmental architecture of the enterprise's resources] [in:] Stankiewicz, M. J. (ed.), Pozytywny Potencjat Organizacji: Wstęp do użytecznej teorii zarzqdzania [Positive Organizational Potential: The introduction to the positive theory of management]. TNOiK Dom Organizatora, Torun 2010.

Guthridge, M., Komm, A. B., Lawson, E., Making talent a strategic priority, "The McKinsey Quarterly", 1, pp. 49-58, 2008.

Haffer, R., Relacje między komponentami modelu wewnatrzorganizacyjnych oddziatywań Pozytywnego Potencjalu Organizacji [Relationships among the components of the model of intra-organizational antecedents of Positive Organizational Potential] [in:] Stankiewicz, M.J. (ed.), Pozytywny Potencjat Organizacji: Wstęp do użytecznej teorii zarzadzania [Positive Organizational Potential: The introduction to the positive theory of management]. TNOiK Dom Organizatora, Toruń 2010.

Haffer, R., Mechanisms of the key Positive Organizational Potential areas impact on organizational development [in:] Stankiewicz, M. J. (ed.), Positive Management: Managing the Key Areas of Positive Organizational Potential for Company Success. TNOiK Dom Organizatora, Torun 2013.

Heinen, J. S., O'Neill, C., Managing talent to maximise performance, "Employment Relations Today”, 31(2), pp. 67-82, 2004.

Ingham, J., Closing the talent management gap: Harnessing your employees' talent to deliver optimum business performance, "Strategic HR Review", 5(3), pp. 20-23, 2006.

Jarosławska, A., Docenić talenty [Appreciating the talents], "Personel i Zarządzanie", 1, pp. 32-36. 2011.

Karaszewski, R., Lis, A., Wewnatrzorganizacyjne uwarunkowania rozwoju kluczowych obszarów pozytywnego potencjatu organizacji [Intra-organizational antecedents of developing the key areas of positive organizational potential] [in:] Wachowiak, P., Winch, S. (eds.), Granice 
$w$ zarzqdzaniu kapitatem ludzkim [The frontiers in managing human capital]. Warsaw School of Economics, Warsaw 2014.

Kaye, B., Jordan-Evans, S. Zatrzymaj najlepszych: 26 strategii budowania zaangażowania pracowników [Retain the best: 26 strategies of building employees' engagement]. Wolters Kluwer Polska, Warsaw 2012.

Kim, Ch. H., Scullion, H., Exploring the links between corporate social responsibility and global talent management: A comparative study of the UK and Korea, "European Journal of International Management", 5(5), pp. 501-523, 2011.

Kim, Ch. H., Scullion, H., The effect of corporate social responsibility (CSR) on employee motivation: A cross-national study, "Poznań University of Economics Review", 13(2), pp. 5-30, 2013.

Kopeć, J., Zarzqdzanie talentami w przedsiębiorstwie [Talent management in an enterprise]. Publishing House of Cracow University of Economics, Crakow 2012.

Koziński, J., Wiskowska, L., Talent ciagle w cenie - wyniki badania Zarzqdzanie talentami [Talent is still valuable - the findings of talent management research], "Nowoczesna Firma", pp. 24-30, 2009.

Lewis, R. E., Heckman, R. J., Talent management: A critical review, "Human Resource Management Review”, 16(2), pp. 139-154, 2006.

Mayo, A., Talent management in troubled times, "Finance \& Management", March, pp. 24-27, 2009.

McCauley, C., Wakefield, M., Talent management in the 21st century: Help your company find, develop, and keep its strongest workers, "Journal for Quality and Participation”, 29(4), pp. 4-7, 2006.

McDaniel, S., D'Egidio, E., Building functional expertise to enhance organizational capability [in:] Silzer, R., Dowell, B. E. (eds.), Strategy-driven Talent Management: A Leadership Imperative. John Wiley \& Sons Inc., San Francisco 2010.

McDonnell, A., Still fighting the 'war for talent'? Bridging the science versus practice gap, "Journal of Business and Psychology", 26(2), pp. 169-173, 2011.

Merlino, M., Talents and technology: A model for policy makers, "Journal of Business Management", 4, pp. 15-20, 2011.

Minbaeva, D., Collings, D. G., Seven myths of global talent management, "The International Journal of Human Resource Management”, 24(9), pp. 1762-1776, 2013.

Pace, A., Unleashing positivity in the workplace, "T+D”, pp. 40-44, 2010.

Peyrat-Guillard, D., Glińska-Neweś A., Positive organizational potential, organizational commitment and organizational citizenship behavior: A French/Polish comparison, “Journal of Positive Management”, 1(1), pp. 47-64, 2010.

Pilbeam, S., Corbridge, M., People Resourcing and Talent Planning: HRM in Practice. Prentice Hall, London 2010.

Piskorski, M. J., Pohrybieniuk, P., Sobieszek, K., Korolec, O., Wilczyński, E., Wiśniewski, P., Jacaszek A., Skuteczny marketing na platformach społecznościowych [Effective marketing in social media platforms], "Harvard Business Review Polska", pp. 90-101, 2010.

Pocztowski, A., Istota talentu i zarzqdzania talentami [The idea of talent and talent management] [in:] Pocztowski, A. (ed.), Zarzqdzanie talentami w organizacji [Talent management in an organization]. Wolters Kluwer, Cracow 2008. 
Reed, A., Innovation in Human Resource Management: Tooling up for the Talent Wars. CIPD Publishing, London 2001.

Reilly, P., Identifying the right course for talent management, "Public Personnel Management", 37(4), pp. 381-387, 2008.

Ringle, C. M., Wende, S., Will, A., SmartPLS 2.0 (beta). University of Hamburg, Hamburg 2005. http://www.smartpls.de (accessed: 22.10.2015).

Sekerka, E., Vacharkulksemsuk, T., Fredrickson, B.L., Positive emotions: Broadening and building upward spirals of sustainable enterprise [in:] The Oxford Handbook of Positive Organizational Scholarship. Oxford University Press, Oxford 2012.

Seligman, M. E. P., Psychologia pozytywna [Positive psychology] [in:] Czapiński, J. (ed.), Psychologia pozytywna: Nauka o szczęściu, zdrowiu, sile i cnotach człowieka [Positive psychology: The science of human happiness, health, strenghth and virtues]. PWN, Warsaw 2004.

Skuza, A., Scullion, H., McDonnell, A., An analysis of the talent management challenges in a post-communist country: The case of Poland, "The International Journal of Human Resource Management”, 24(3), pp. 453-470, 2013.

Sloan, E. B., Hazucha, J. F., van Katwyk, P. T., Strategic management of global leadership talent, "Advances in Global Leadership", 3, pp. 235-274, 2003.

Sosińska, N., Magia rozwoju talentów: Jak zdobyć, zatrudnić i zatrzymać właściwych ludzi $w$ firmie [The magic of talent development: How to get, employ and retain the right people in a firm]. IFC Press, Cracow 2007.

Surmacz, B., Bociąga, A., Prześwietlony wizerunek: Employer branding jako szansa dla firm [X-rayed image: Employer branding as an opportunity for firms], "Personel i Zarządzanie", 3, pp. 50-54, 2011.

Tabor, J., Zarzqdzanie talentami w przedsiębiorstwie: Koncepcje, strategie, praktyka [Talent management in an enterprise: Concepts, strategies practice]. Poltext, Warsaw 2013.

Talent management is Bupharm's prescription for success: Family-owned firm competes effectively with the multinationals, "Human Resource Management International Digest", 18(1), pp. 11-13, 2011.

Tansley, C., Turner, P., Foster, C., Harris, L., Stewart, J., Sempik, A., Williams, H., Talent: Strategy, Management, Measurement. CIPD, London 2007.

Tarique, I., Schuler, R. S., Global talent management: Literature review, integrative framework, and suggestions for further research, "Journal of World Business", 45(2), pp. 122-133, 2010.

Taylor, S., Resourcing and Talent Management. CIPD, London 2010.

Trendy HR [HR trends], 2013. http://www.hrtrendy.pl/2013/03/18/trendy-hr-2013-wnioski-zbadania/ (accessed: 22.10.2015).

Turning talent into strategic assets: Employee awareness of their own impact, "Human Resource Management International Digest”, 18(3), pp. 23-25, 2010.

Ulrich, D., Younger, J., Brockbank, W., Ulrich, M., HR talent and the new HR competencies, "Strategic HR Review", 11(4), pp. 217-222, 2012.

Vaiman, V., Collings, D.G., Talent management: Advancing the field, "International Journal of Human Resource Management”, 24(9), pp. 1737-1743, 2013. 
Vaiman, V., Scullion, H. Collings, D., Talent management decision making, "Management Decision", 50(5), pp. 925-941, 2012.

Williamson, D., Talent management in the new business world: How organizations can create the future and not be consumed by it, "Human Resource Management International Digest", 19(6), pp. 33-36, 2011.

Yaqub, B., Khan, M. A., The role of employer branding and talent management for organizational attractiveness, "Far East Journal of Psychology and Business", 5(1), pp. 57-65, 2011.

Zarzadzanie talentami: Zarzqdzanie talentami i rozwój pracowników $w$ organizacji [Talent management: Managing talents and employees' development in an organization]. https:// app.mapaorganizacji.pl/Content/mapa-organizacji/19-zarzadzanie-talentami. html\#Problem, (accessed 22.10.2015).

Zydel, R., Młodzi w krzywym zwierciadle [The young in the distorting mirror], "Harvard Business Review Polska”, pp. 55-65, 2010.

Received: April 2018

Acknowledgement: The study is based on the empirical data collected under the umbrella of the research project entitled Strategic management of the key areas of Positive Organizational Potential - determinants, solutions and models recommended for companies operating in Poland. The project was funded by the National Science Centre research grant (decision number DEC-2011/01/B/HS4/00835). 


\section{APPENDIX}

Variables of the talent management antecedents model

\begin{tabular}{|c|c|}
\hline Latent variables & Manifest variables \\
\hline 1 & 2 \\
\hline $\begin{array}{l}\text { 1. Talent } \\
\text { management } \\
(\mathrm{TM})\end{array}$ & $\begin{array}{l}\text { a. A company makes talent management an element of its strategy } \\
\text { b. A company knows what talents are required } \\
\text { c. A company has relevant methods to identify and select talents } \\
\text { d. A company makes an effort to attract the best employees } \\
\text { e. A company establishes individual paths of career and methods of } \\
\text { development for talents } \\
\text { f. A company creates opportunities for talents to meet ambitious projects } \\
\text { and challenges } \\
\text { g. A company creates conditions for learning and knowledge sharing }\end{array}$ \\
\hline $\begin{array}{l}\text { 2. Organizational } \\
\text { strategy } \\
\text { (STRAT) }\end{array}$ & $\begin{array}{l}\text { a. The company strategy combines the interests of employers and } \\
\text { employees } \\
\text { b. Employee opinions are taken into account in the strategy formulation } \\
\text { process } \\
\text { c. Strategic goals are clearly formulated and fully communicated to } \\
\text { employees } \\
\text { d. The progress and effects of the strategy implementation process are } \\
\text { honestly and openly communicated }\end{array}$ \\
\hline $\begin{array}{l}\text { 3. Talent } \\
\text { management } \\
\text { infrastructure } \\
\text { (TM INFRA) }\end{array}$ & $\begin{array}{l}\text { a. HRM procedures are transparent and consistently applied } \\
\text { b. A company sets high requirements for candidates to be employed (elitist } \\
\text { employment) } \\
\text { c. HRM decisions are combined with an appraisal and evaluation process } \\
\text { d. A company has systems and procedures for fair and honest appraisal and } \\
\text { evaluation of its employees } \\
\text { e. Employees experience the feeling of justice in their workplace } \\
\text { f. A company has the necessary tools for recruitment and selection of the } \\
\text { key employees } \\
\text { g. Employees of relevant qualifications, skills and personal competencies } \\
\text { are appointed to perform the tasks } \\
\text { h. A company has enough financial resources to recruit the best employees } \\
\text { i. Workplaces are equipped with attractive amenities }\end{array}$ \\
\hline $\begin{array}{l}\text { 4. Development } \\
\text { opportunities } \\
\text { for talented } \\
\text { employees } \\
\text { (DEV OPP) }\end{array}$ & $\begin{array}{l}\text { a. A company set ambitious aims and objectives for its employees } \\
\text { b. Innovative behaviours are highly recognized and rewarded } \\
\text { c. A company has a comprehensive training system enabling the } \\
\text { development of its employees } \\
\text { d. A company increases the employee autonomy and responsibility } \\
\text { e. Managers delegate their responsibilities to lower levels of management } \\
\text { f. Training programs accommodate the needs of employees } \\
\text { g. Achievements are the main criteria for evaluating employees }\end{array}$ \\
\hline
\end{tabular}




\begin{tabular}{|c|c|}
\hline 1 & 2 \\
\hline $\begin{array}{l}\text { 5. Intra- } \\
\text { organizational } \\
\text { communication } \\
(\mathrm{COM})\end{array}$ & $\begin{array}{l}\text { a. The system of internal communication provides necessary information to } \\
\text { all employees and ensures the feedback } \\
\text { b. Internal communication is unambiguous and delivered on time } \\
\text { c. Message senders analyze the emotions of their interlocutors and adjust } \\
\text { the form of communication to them } \\
\text { d. Internal communication enhances employee motivation } \\
\text { e. Internal communication fosters integration among employees } \\
\text { f. Internal communication consistently and coherently explains the } \\
\text { organizational values to be respected } \\
\text { g. The systems and procedures for effective internal communication (both } \\
\text { vertical and horizontal) are established } \\
\text { h. Face-to-face communication is preferred in a company } \\
\text { i. Managerial staff and employees have effective communication skills } \\
\text { j. The language of communication used in a company is understandable to } \\
\text { all employees } \\
\text { k. A company openly communicates pending problems }\end{array}$ \\
\hline $\begin{array}{l}\text { 6. Organizational } \\
\text { culture (incl. } \\
\text { interpersonal } \\
\text { relationships } \\
\text { and trust) } \\
\text { (CULT) }\end{array}$ & $\begin{array}{l}\text { a. Employees are interested in and participate in the company everyday life } \\
\text { b. Employees help each other in solving important, job-related problems } \\
\text { c. Organizational culture fosters seeking excellence } \\
\text { d. Organizational culture is clear and understandable } \\
\text { e. A company enjoys good reputation } \\
\text { f. Employees are satisfied with their jobs } \\
\text { g. Employees show a high level of identification with their company } \\
\text { h. Employees can count on each other } \\
\text { i. Employees show interest in each other } \\
\text { j. Employees are frank with each other } \\
\text { k. Employees like each other } \\
\text { 1. Employees show acceptance and respect for each other } \\
\text { m. Condition of interpersonal relationships in employee teams translates } \\
\text { into relationships among the teams in a company } \\
\text { n. Working teams are characterized by a high level of cohesion } \\
\text { o. Employees communicate in an open and sincere way and they share } \\
\text { information on the mistakes they have made without being afraid of } \\
\text { negative and unjust consequences } \\
\text { p. Employees are committed to their jobs, even when a company faces } \\
\text { difficulties (crisis periods) } \\
\text { q. Employees willingly share knowledge } \\
\text { r. Employees play fair even when they compete with each other } \\
\text { s. There is the climate of friendliness within a company } \\
\text { t. The superiors are not anxious to delegate their responsibilities and powers } \\
\text { u. Employees do not resist managerial decisions } \\
\text { v. Self-control is applied wherever possible }\end{array}$ \\
\hline $\begin{array}{l}\text { 7. Organizational } \\
\text { structure } \\
\text { (STRUCT) }\end{array}$ & $\begin{array}{l}\text { a. An optimum formalization is in place combining both precise and clear } \\
\text { procedures (when needed) and informal activities } \\
\text { b. Organizational structures are transparent } \\
\text { c. The responsibilities of employees are clear and complete } \\
\text { d. A company emphasizes teamwork } \\
\text { e. The members of project teams can be freely identified and nominated } \\
\text { f. Formal procedures and rules do not limit creativity }\end{array}$ \\
\hline
\end{tabular}


Variables of the talent management antecedents model (cont.)

\begin{tabular}{|c|c|}
\hline 1 & 2 \\
\hline $\begin{array}{l}\text { 8. Middle-level } \\
\text { management }\end{array}$ & $\begin{array}{l}\text { a. Managers perform leadership roles in their teams } \\
\text { b. Managers coordinate their teams and foster relations } \\
\text { c. Managers perform coaching roles in their teams } \\
\text { d. Managers capture and disseminate information on business goals and } \\
\text { objectives } \\
\text { e. Managers initiate changes in a company } \\
\text { f. Through their behaviour, managers set a good example of positive } \\
\text { relations within a team and outside it } \\
\text { g. Managers are oriented to self-development and increasing their skills and } \\
\text { competencies } \\
\text { h. Recruitment criteria for managerial positions include necessary } \\
\text { knowledge and skills (resulting from the work position) } \\
\text { i. Recruitment criteria for managerial positions include social competencies } \\
\text { (appearance, establishing relations, communication skills, teamwork) } \\
\text { j. Recruitment criteria for managerial positions include emotional } \\
\text { competencies (empathy, self-consciousness, self-control, self-motivation) } \\
\text { k. Recruitment criteria for managerial positions include individual } \\
\text { effectiveness (ability to work in stress, concentration) } \\
\text { 1. The middle management provides a positive model of relations with } \\
\text { employees }\end{array}$ \\
\hline $\begin{array}{l}\text { 9. Corporate social } \\
\text { responsibility }\end{array}$ & $\begin{array}{l}\text { a. A company has established HRM policies taking into account the } \\
\text { outcomes of surveys among employees (monitoring the employee } \\
\text { satisfaction, the development of their careers, work conditions, leaves, } \\
\text { safety and remuneration) } \\
\text { b. A company has established fair and transparent rules applied to its } \\
\text { relations with employees and other stakeholders - when running business } \\
\text { the company takes into account the interest of society } \\
\text { c. A company has developed and introduced the OH\&S (Organizational } \\
\text { Health and Safety) procedures going beyond the obligatory legal } \\
\text { regulations } \\
\text { d. A company contributes to the development of its local community } \\
\text { (cooperation with local business, job creation, education) } \\
\text { e. A company systematically supports the underprivileged (it contributes to } \\
\text { the improvement of their living conditions) } \\
\text { f. A company has established the aims of reducing its negative impact on } \\
\text { the natural environment (i.e. the average energy or water consumption) } \\
\text { g. Corporate social responsibility issues have been included into a strategy } \\
\text { h. The criteria for contracting suppliers are not limited to an economic } \\
\text { dimension } \\
\text { i. The responsibility for planning and coordinating CSR policy is formally } \\
\text { established (i.e. a position or a department responsible for CSR } \\
\text { implementation, procedures and regulations) }\end{array}$ \\
\hline
\end{tabular}

